University at Buffalo School of Law

Digital Commons @ University at Buffalo School of Law

\title{
Biopolarity: Coral Scientists Between Hope and Despair
}

Irus Braverman

University at Buffalo School of Law

Follow this and additional works at: https://digitalcommons.law.buffalo.edu/journal_articles

Part of the Environmental Law Commons

\section{Recommended Citation}

Irus Braverman, Biopolarity: Coral Scientists Between Hope and Despair, Anthropology Now, Dec. 2016, at 26.

This is an Accepted Manuscript of an article published by Taylor \& Francis in Anthropology Now on 12/09/2016, available online: https://www.tandfonline.com/doi/full/10.1080/19428200.2016.1242908.

\section{C) ${ }_{\text {COPYRIGHT }}^{\text {N }}$}

This Article is brought to you for free and open access by the Faculty Scholarship at Digital Commons @ University at Buffalo School of Law. It has been accepted for inclusion in Journal Articles by an authorized administrator of Digital Commons @ University at Buffalo School of Law. For more information, please contact lawscholar@buffalo.edu. 
DRAFT. Anthropology Now. Volume 8 | Issue 2 | December 2016 (forthcoming)

\section{Biopolarity: Coral Scientists between Hope and Despair}

\section{Irus Braverman}

\section{On Conferences and Bathrooms}

On July 5, 2016, I returned from the International Coral Reef Symposium (ICRS) in Hawai'i. Some 2,500 coral scientists, managers and policy makers from 70 countries had convened there, as they do every four years, to discuss the present and future of tropical coral reefs. The meeting was overwhelming. Waves of "coral people" from around the globe and dozens of simultaneous sessions made it a frenzied affair. As one of the scientists I was trying to follow during the meeting wrote me in an e-mail: "PS. yes I am at ICRS running around like a headless chicken like everyone else." My only relatively quiet moment during this weeklong conference happened in the bathroom, where I took a moment to reflect on how unsettled I felt and what it was about this conference that got me feeling so discombobulated.

The answer came in a flash, complete with a title: biopolarity. I have been contemplating Michel Foucault's term "biopolitics," which he uses to highlight the processes through which life is made invaluable, a "making live." I have been documenting precisely which animal lives are privileged in conservation discourses and how such value judgments are made by biologists, who make them seem natural, even inevitable. What I experienced at the international coral reef meeting was the oscillation of coral "make live" between the extremes of hope and despair. The term biopolarity captures this oscillation while paying tribute to how Foucault's biopolitics has influenced my way of thinking.

\section{Hope, Despair, Hope, Despair: The Pendulum Affect}

At one extreme of the oscillation are catastrophic predictions of the death of corals by the mid$21^{\text {st }}$ century. ${ }^{2}$ In this despondent narrative, corals are getting fried and nothing short of an abrupt (and unlikely) shift in how humans use fossil fuels will save them. As a central proponent of this approach, Ove Hoegh-Guldberg told me in an interview: "The Titanic is sinking and what we are doing is rearranging the chairs to get a better view." 3 The pessimistic trajectory of this swing of the pendulum comes replete with daunting maps, images, and algorithms, documented, for example, by the recent, highly reported and minutely recorded coral bleaching events in the northern Great Barrier Reef — whereby huge tracks of coral animal colonies have lost their symbiotic algae and are thereby embarking on a quick and whitened path toward death. Of 520 reefs north of Cairns in Australia surveyed in 2016, 95 percent were severely bleached; only four were ranked healthy. "This will change the Great Barrier Reef forever," coral scientist Terry Hughes told Australia's ABC. ${ }^{4}$

On the other extreme are narratives of hope for coral futures to come. "Give me the dying corals that you have given up on and I will restore them," pleaded a coral restoration scientist to a large and visibly uncomfortable audience at an evening plenary. Trendy terms have been coined recently to represent actions humans can take in the face of the growing threats to coral life. These include "bright spots," which highlights locations where humans have been able to strengthen coral resilience and reverse the trend for coral death, ${ }^{5}$ and "assisted evolution," the selected captive breeding of "super corals" for transplantation in order to strengthen depleted coral colonies. "From despair to repair," as one prominent coral scientist put it." 
Under the hashtag \#OceanOptimism, another prominent scientist has been documenting hopeful news about the oceans. "We don't want people going into a catatonic state of sitting in the corner and moaning because all is lost," coral reef ecologist Peter Sale explained in an interview. ${ }^{9}$ Accordingly, many scientists are moving away from the predominant "doom and gloom" discourse around coral conservation to focus on collaboration and action, highlighting that "there is room for ocean optimism on the coral reef front." 10

Both stances toward the corals' future carry considerable emotional intensity. Most striking for me, however, is not so much the intensity of the despair and hope messages but the disconnect, the alienation even, between them. Many coral scientists cannot hold hope and despair simultaneously, instead choosing one over the other for the duration of their scientific careers or alternating between the two in shorter time spans. ${ }^{11}$

I must admit to my own oscillation between these extremes. I spent my teenage summers scuba-diving in the Red Sea in Sinai, Egypt. But life has taken me away from the ocean for 20 years, and much has happened to coral reefs since then. I didn't realize just how much until my visit to a reef in Culebra, a small island off the main shore of Puerto Rico, in January 2015. I was there to conduct research for my book Wild Life, ${ }^{12}$ which explores the relationship between captive and wild sites of nature management. Coral nurseries provided an interesting example, and I was planning to dedicate a few pages to restoration efforts in the ocean. Puerto Rican coral scientist Edwin Hernandez-Delgado proudly showed me around his underwater coral nursery and spoke about his efforts in outplanting Acropora species from the nursery into the devastated reefs of Culebra. All the while, a voice in my head incessantly repeated: "But where are the corals? Where are the corals?"

\section{$\{\{$ Figure 1 goes here $\}\}$}

$\{\{$ Figure 2 goes here $\}\}$

This sudden, unmitigated realization that not all is well underwater prompted my decision to dedicate more research and writing to corals. It helped that coral scientists are a tight-knit community: Edwin was able to put me in touch with Australian scientists as I visited the Great Barrier Reef in May 2015 and with Israeli coral managers for my June 2015 visit to the Red Sea. Unfortunately, the sites where I scuba-dived in the northern Great Barrier Reef have since then become either bleached or dead in what has been the most acute global bleaching event on record. Diving in the Red Sea was not a very uplifting experience either. The sites I knew well have been closed to the public because of their degraded condition.

My personal narrative reflects the state of things for many coral scientists, who deal with this biopolarity even more intensely as they decide which corals ought to live and which not and then must justify their actions - both to themselves and to others — on a routine basis. When reading the barrage of depressing reports from the Great Barrier Reef, I wondered how, in the face of such devastation, these scientists find the "umph" required to proceed in their dedicated work. "What is the point in saving corals if they will eventually die of global warming and ocean acidification anyway?" I remember asking Nilda Jimenez in 2014. Nilda is an employee of Puerto Rico's Department of Natural and Environmental Resources and was my first coral interviewee. Her daily labor consisted of tying corals together with dental floss to affix them to the ocean floor in an attempt to restore them from white-band disease. Nilda responded to my question that the only other alternative was doing nothing and this is not something she could live with. ${ }^{13}$ Two years later, marine biologist Nancy Knowlton of the Smithsonian succinctly tweeted along the same lines: "Bleaching is bad but giving up is worse."14 
That kind of active approach made sense; it was inspiring even. Yet just a few interviews later, a self-defined "realistic" scientist ${ }^{15}$ swayed me to the other extreme. Instead of wasting time restoring coral fragments that will again die from similar stressors, scientists should focus their energy on the real changes that need to happen: affecting climate change and ocean acidification.

And so I have been swaying, from hope to despair, from despair back to hope.

What I didn't expect, however, is the extent to which the two approaches are alienated from one another. Specifically, I witnessed an attitude of cynicism and contempt, especially from the doom and gloom protagonists toward the restoration people. "Restoration is crap," Australian coral ecologist Andrew Baird told me bluntly during a much-needed break at the ICRS. He was happy to be quoted on this matter, which he insisted was of grave scientific importance to coral science broadly. Three full sessions in the conference were dedicated to this unscientific topic, he complained, while barely one full session was about coral ecology. Whereas others might not have been so blunt, the tensions surfaced clearly and produced awkward moments, despite the conference organizers' attempt to present a united front.

I am interested in these tensions and in what they represent. I would offer that they go deeper than localized personal and professional disagreements: they signify the emerging break between conservation and what some refer to as the new environmentalism. As I document in Wild Life, while more traditional conservationists aspire to recreate ecosystems in light of their past histories and imaginaries, new environmentalists see nature as a garden that can and must be tinkered with and intensely managed. ${ }^{16}$ Rather than seeing humans as "screwing it up," as many traditional conservationists would have it, some see hope in human-nonhuman networks and collaborations and seek to foster such connections.

The narrative below mirrors this hope-despair pendulum. I start with stories of coral restoration, then move to discuss the latest bleaching event and its extensive monitoring. Finally, I explore "assisted evolution" and the project of making "super corals."

\section{Restoration: Hope}

Sarah Frias-Torres grew up in Barcelona and spent her childhood on the Mediterranean. "Actually, I learned how to snorkel before I learned how to swim," she told me. ${ }^{17}$ She transitioned from lab research in marine science to applied research in conservation and restoration. "When I began scuba diving as a marine biologist," she explained, "the Mediterranean that I was seeing wasn't the one that [Jacques] Cousteau showed [on television]. It changed completely; there were no fish. And so that's what got me to say, 'Okay, I need to work on conservation.' But there comes a point when you see you've got to do more. So now I'm both in conservation and restoration." The split between conservation and restoration might not be evident to an outsider. While conservationists have traditionally advocated preservation and protection of habitats and species with minimal human intervention, restoration ecologists advocate humans' active engagement, not unlike with gardening above water.

Sarah and I communicated extensively over e-mail. We finally ran into each other at the ICRS banquet dinner. The singing, dancing and clapping didn't stop Sarah from outlining her detailed agenda for saving corals. "The restoration of the planet is the greatest challenge of our century, of our lifetime even," she yelled over the noise. "If we don't work on it, there is no future. And I'm not talking about the future for our children, because I don't think as a species 
we really care about our children or we wouldn't be behaving as we are. So I would suggest just conserve and restore for yourself and your lifetime."

Sarah's passionate belief in the power to restore is contagious, but she also seems frustrated. Many of her colleagues from the traditional coral conservation world give restoration folks a hard time, claiming that restoration is not a science, that it cannot be carried out at a scale that matters for corals, that it is taking both funding and attention away from real conservation, that it is naïve. Still yelling over the background sounds, she responded to each and every accusation: restoration projects that do not adhere to scientific restoration principles have given restoration projects that do a bad reputation, she stated. Due to technological advancements restoration can increasingly be performed on an adequate scale, given the proper funding. The funding for restoration does not come from the same pot as that for conservation. Finally, Sarah asserted that it is conservationists who are being rigid and naïve, in that they are not willing to admit that the world has fundamentally changed and will never again return to its pristine state. In what would be perceived by conservationists as a controversial statement, Sarah told me: "You need to do the restoration to jump start nature because nature is so far gone it's not going to do it by itself."

The night prior to our conversation featured a roundtable with all the "big names" in coral conservation. Sarah provoked the speakers and audience with the following statement:

I learned this from a pediatrician working in poor villages in South America. He said that in the emergency room they don't have the resources to attend all the babies and little children at once. When in a triage situation, they only help the babies that are crying. Because if they are crying, it means they are strong enough, they still have some life in them, that the medical treatment will be useful. For the babies that don't cry, there's no help. We are now in triage. ... We can only save the coral reefs that are still crying. Crying for help. Because they still hold enough life that the conservation effort will be useful. What to do with the others? As a coral reef restoration scientist, I ask you: Give us the rejects. Give us the dead and the dying. We'll patch them up. . . Conservation and restoration [should] work together. In this way, coral reefs still stand a chance at survival.

An uncomfortable silence followed. A few long seconds later, the next question was raised and the conversation shifted away. The plea to accept restoration as a legitimate addition to conservation efforts rather than an unwanted child of conservation was avoided — at least for the time being. Tensions surfaced again shortly after, when the facilitator asked Australian scientist Ove Hoegh-Guldberg, who is widely known among coral scientists as the "doom and gloom" expert, whether all strategies to save corals are now game, in light of their degraded state. Ove responded with a graph, arguing that even if humans balance out emissions, temperatures will still climb until mid-century at least. Then, he continued, it would be time to do restoration and "super coral" projects. "But at the moment," he emphasized, "it makes no sense because you put [corals] into the ocean and they grow for a while and then bleaching comes along and they die." A member of the audience fiercely objected to this statement. Ove's response was that he didn't mean to say that we can now just sit back and witness the decline and do nothing; quite the contrary, local efforts are crucial and one must learn about corals in order to prepare for the time when restoration would not be futile.

While the debate between conservation and restoration continues, between 2013 and 2015 Sarah cultivated 40,000 corals in 13 ocean nurseries that she and her team built in the 
Indian Ocean on the African island nation of Seychelles. Despite two freak events that killed about 7,500 corals - a hurricane and an invasive encrusting sponge - Sarah and her team transplanted 25,000 corals from 34 species onto half a hectare of degraded reef. She reported that the transplanted coral reef has significantly increased fish numbers and that new baby corals have settled in the colony from elsewhere, a sure sign that "restoration is working." 18

$\{\{$ Figure 3 goes here $\}\}$

\section{Monitoring Bleaching: Despair}

After months of intensive aerial and underwater surveys, in May 2016 researchers from the Australian ARC Centre for Excellence released an initial estimate of the death toll from coral bleaching in the Great Barrier Reef. The massive bleaching has killed 35 percent of corals on the northern and central sections of the 2300-kilometer-long Great Barrier Reef system, the researchers reported in that month's issue of Science. ${ }^{19}$ On 24 of the 84 reefs surveyed, 50 percent of the corals have perished, including specimens that were 50 to 100 years old.

$\{\{$ Figure 4 goes here $\}\}$

$\{\{$ Figure 5 goes here $\}\}$

While predicted quite accurately, the 2016 bleaching percentages at the Great Barrier Reef and other locations still caught many coral scientists by surprise. "It feels like a very special person whom you just started to get acquainted with suddenly dies on you," Joanie Kleypas told me about the coral colonies in Costa Rica with whom she has been working. "I "I feel so helpless," the ocean scientist added with genuine sadness in her voice. The bleaching and death are caused by higher-than-normal temperatures due to climate change, coupled with an El Niño event.

And the end is not in sight, the National Oceanic and Atmospheric Administration (NOAA) predicts. Extensive coral bleaching on many of the world's reefs over the past two years has highlighted the corals' susceptibility to thermal stress, with global warming "only" at $0.9 \mathrm{C}$ to date. The increasing high temperatures will likely result in further damage to reefs in Hawai'i, Guam, the Commonwealth of the Northern Mariana Islands, the Caribbean and the Gulf of Mexico. There is a 90 percent chance of widespread coral bleaching in the Pacific island nations of Palau and the Federated States of Micronesia during the La Niña event that often succeeds the El Nino, according to NOAA. ${ }^{21}$ After releasing this data, Jennifer Koss, NOAA's Coral Reef Conservation Program director, was quoted saying: "We have boots on the ground and fins in the water to reduce local stressors. Local conservation buys us time, but it isn't enough. Globally, we need to better understand what actions we all can take to combat the effects of climate change." 22

Among the numerous bleaching monitoring projects that pop up by the day, Coral Reef Watch (CRW) is probably the most established and expansive. CRW was instituted by the United States government during the first documented global bleaching event in 1989. Its mission: "to use remote sensing and onsite tools for near real-time and long-term monitoring, modeling, and reporting of physical environmental conditions of coral reef ecosystems." ${ }^{23} \mathrm{CRW}$ uses climate- monitoring satellite data to inform marine park managers and scientists when corals might be at risk for bleaching. Based on data collected from coral reef scientists in the field, CRW concluded that corals begin to bleach when the temperature of the sea surface (SST) exceeds the average for the typically warmest month by one degree Celsius. CRW took this data and produced an online experimental chart that displayed where these areas of high SSTs will be 
found in "real-time" across the tropics. This data, referred to as "HotSpot charts," is obtained by satellites and made available over the internet. ${ }^{24}$

In 2005, CRW added a new "product" to HotSpot: an automatic e-mail with "Satellite Bleaching Alert," or SBA, is sent to subscribers each time the alert status changes. Based on the HotSpot levels, CRW has been issuing four levels of alert for reef sites. Since subscribing to this free-to-the-public-but-hardly-decipherable alert in November 2015, I have been receiving weekly e-mail notifications about the state of bleaching in my sites of choice, which I randomly picked from NOAA's 227 sites around the globe. ${ }^{25}$ After opening the first few e-mails, I now only glance quickly at the titles and move on. This reminds me of something Nancy Knowlton-the "mother" of \#OceanOptimism, which has received more than 59-million posts since its initiation in 2014 - told me over Skype recently. "You present people with large problems and no solutions and they just go to the bar," she said. "Why get upset about something that you can't do anything about? Even I, there are lots of stories in scientific venues that I don't bother to read. I know it's bad news, it's just more details about how bad it is. There's only so much doom and gloom that I can carry." 26

Shortly after the ICRS, I attended a workshop directed by CRW Coordinator Mark Eakin and his Australian colleague, William Skirving. The workshop was held at the University of Hawai' $i$ in Hilo with the goal of familiarizing scientists and community activists with the products available for the monitoring and prediction of coral bleaching, and obtaining their input on these products. At the break, I approached William. What follows is the gist of our conversation:

$I B$ : What [in the monitoring project] are you proudest of?

WS: I guess the fact that we've described, or predicted, months in advance, this current bleaching event, where it would strike.

$I B:$ In the Great Barrier Reef or everywhere?

WS: Everywhere. The outlook product that we have indicated that the northern Great Barrier Reef would bleach and I, for one, was saying I can't believe our own product.

$I B$ : How long in advance did it predict this?

WS: Three or four months.

$I B:$ And did it help that it predicted it? Did it change things?

WS: [How do] you mean?

$I B$ : I mean in terms of management.

WS: Oh, no. This bleaching event has been documented better than any other bleaching event we've ever had. It mobilized all the efforts of documenting it. Will it change the way [reefs are] managed? [The Great Barrier Reef] is already very rigorously managed, so no, that won't change. When a bleaching event is underway they don't change the way they manage.

$I B$ : But maybe [it will change] the Australian government's licensing of mining companies and all that?

WS: Ah, that aspect of things. Well, that is a different story altogether. 


\section{$I B$ : Is it?}

WS: Unfortunately, in Australia it's not much different than the United States. In effect you've got the politicians working to get back into power, their time horizon is short, so they're looking for short-term gains not long-term gains. And the short-term gains are jobs, not climate change. And that's the big problem. The big question. ${ }^{27}$

$\{\{$ Figure 6 goes here $\}\}$

Terry Hughes, renowned for "ground-truthing" (as scientists refer to the process of checking the actual sites to verify the broader predicaments) the extent of bleaching in the Great Barrier Reef, told Nature earlier this year: "The main issue is obviously reducing greenhouse-gas emissions. Here in Australia, that's very controversial, because our government is trying to prolong the export of coal. The Commonwealth Government of Australia has recently issued a lease for a new coal mine in Queensland. It will export its coal across the Great Barrier Reef, so shipping and dredging will all increase if this coal mine proceeds. Obviously, the last thing the Great Barrier Reef needs is more coal mines." 28

Along the same lines, the Australian government lobbied against and censored UNESCO's 2016 climate change report, demanding that any mention of the Great Barrier Reef be left out. ${ }^{29}$ And while global warming is admittedly at the heart of the problem, many coral scientists shy away from calling for the relevant regulatory changes in fossil fuel emissions, which they perceive as a political and global topic they have little influence on, rather than as a scientific and local topic they may be able to affect. Yet despite what are arguably the limited impacts of NOAA's bleaching predictions, none of the coral reef scientists I spoke with question the importance of monitoring, even if only for the sake of knowing and recording. They are, after all, scientists - not policy makers.

Although it was held before the current and most intense bleaching event, my interview with Ove was probably the gloomiest of all, as befits his reputation. "If we don't arrest ourselves, we're going to destroy ourselves, a bit like an alcoholic planet," he told me over Skype. "We're going to do all the worse things to ourselves and we'll have only ourselves to blame for it. But we won't quite die; we'll be a shadow of ourselves of course."

"I'm not saying that we shouldn't be trying to refine the techniques," he told me toward the end of our interview. "But until we deal with the climate issue, this is futile." 30

\section{Assisted Evolution: Hope?}

In the final leg of my trip to Hawai'i, I was invited by Ruth Gates, president of the International Society for Reef Studies, to spend the day with her on Coconut Island off the shore of Kaneohe in the eastern part of Oahu. Although she studied and worked with Ove for many years, Ruth's outlook is different. She described her longtime colleagues' Terry and Ove's perspective on coral conservation: "They're saying, 'Well, the system used to look like this, and so we need to get it back to this." From Ruth's perspective, however, "We have no intention to get it back because we are here. And we will either have a reef in the future or we won't. But if we continue down this trajectory and we do absolutely nothing to assist the system, it's likely that we'll have nothing." 31

By "assist the system," Ruth is referring to a radical proposal she has developed together with her colleague, Madeleine van Oppen, to captive-breed corals who have survived the bleaching events and thus are more tolerant of climate change. These are the "super corals" of 
the future, they believe, and the process of propagating and introducing them into strategic locations in the reef will accelerate natural processes that might just be too slow to deal with the rapidity of human-induced climate change.

Ruth is expressly collaborative and supportive of different attempts to save reefs, including restoration. She describes a conversation she had with Terry Hughes:

As I said to Terry, 'Terry, I hate to be blunt, but you think that the restoration and assisted evolution need your blessing, and you know what? The reality is that you are so behind the fast ball. Restoration is happening. Assisted evolution is happening. We are doing it. And guess what? If we don't, there are places that will have no reef left now. Christmas Island has no goddamn corals left. Are they going to wait for you to give them permission before they start doing these things? Absolutely not.'

Still, Ruth criticizes the restoration community for focusing too little on coral genetics. "There's very little attention to the most robust genotypes," she told me. "It's just: we fragment [i.e., perform asexual reproduction, like in plants]. We go quickly, and we don't really pay any attention to genetics."

From her perspective, genetics represent hope for corals. In a Skype interview we held in February 2016, Ruth referred to this type of work as "running our corals on environmental treadmills." Her idea: to incrementally raise coral performance through selective breeding. Supported by a large grant from Microsoft co-founder Paul Allen, she and Madeleine have been designing experiments to preacclimate corals to extreme conditions with the aim of inducing epigenetically controlled stress tolerance that would be passed on to the next generation. ${ }^{32}$ Both go out of their way to stress that this is not genetic modification. Rather than tinkering with genes, they are merely doing what has been done for centuries with wheat and tomatoescrossbreeding for selected traits. "I'm not convinced we can hold it to 1.5 degrees [Celsius], and even a 1.5 [increase] is going to kill a lot of corals," Ruth explained. We have to be realistic about where we are: for the most part, coral reefs are almost all declining. That means it's not sufficient to step back and wait. People tell me nature might do that [by] itself. It might, but it doesn't seem to be. Not quickly enough."

$\{\{$ Figure 7 goes here $\}$ \}

A day with Ruth means a heady dose of positive thinking. "People want to do something, they want to help. The gloom and doom is paralyzing, the scope of the climate change issue is so paralyzing." But not for Ruth. As befits her black belt in Karate, she has taken on the challenges of climate change full force. And like in Karate, she told me, most of the battle to save corals is mental, not physical. "I want to start a movement," she revealed in one of our conversations. "There's people who do that for a living, who manage campaigns. I don't know how to do that. But that's what [saving corals] would entail. We need to empower people to do it."

\section{Acknowledgements}

This work was made possible by OVPRED/HI Seed Money in the Arts and Humanities, 2016. 


\section{Notes}

${ }^{1}$ Michel Foucault, The History of Sexuality, Vol. 1: An Introduction. (New York: Vintage, 1990), 135-136.

${ }^{2}$ Ove Hoegh-Guldberg et al, "Coral Reefs Under Rapid Climate Change and Ocean Acidification." in Science, 318 (2007): 1737-1742.

${ }^{3}$ Ove Hoegh-Guldberg, Director, Global Change Institute \& Professor, Marine Science, the University of Queensland, Brisbane, Australia. Interview by author. Skype, February 25, 2015.

${ }^{4}$ Brad Plumar, "The Unprecedented Coral Bleaching Disaster at the Great Barrier Reef, Explained," in Vox, March 31, 2016. http://www.vox.com/2016/3/30/11332636/great-barrierreef-coral-bleaching

5 Joshua E. Cinner et al, "Bright Spots Among the World's Coral Reefs." in Nature, 2016. DOI: 10.1038/nature18607. See also: "Why Some Coral Reefs Are Thriving: Not All of the World's Reefs are in Bad Shape - and a Few of the Healthiest are Managed by Humans." The Atlantic, June 15, 2016. http://www.theatlantic.com/science/archive/2016/06/the-surprising-bright-spotsamong-the-worlds-coral-reefs/487118/

${ }^{6}$ Madeleine J. H. van Oppen et al, "Building Coral Reef Resilience Through Assisted Evolution." in PNAS, 112 (2015): 2307-2313.

7 Smithsonian's Ocean Portal, "From Despair to Repair: Protecting Parrotfish Can Help Bring Back Caribbean Coral Reefs.” July 2, 2014. http://ocean.si.edu/blog/despair-repair-protectingparrotfish-can-help-bring-back-caribbean-coral-reefs See also: "Major multi-institutional report led by Scripps professor emeritus Jeremy Jackson details the plight and hope of Caribbean corals." https://scripps.ucsd.edu/news/despair-repair-protecting-parrotfish-can-help-bring-backcaribbean-coral-reefs

${ }^{8}$ Nancy Knowlton, "Why I Am an Ocean Optimist,” in The Huffington Post, June 2, 2015. http://www.huffingtonpost.com/nancy-knowlton/why-i-am-an-ocean-optimist_b_7487286.html See also: Kristy Nash,“\#ICRS2016: Are Coral Reef Scientists All Doom and Gloom?” 2016. http://www.kirstynash.com/icrs2016-summary.html

${ }^{9}$ Peter Sale. Marine Ecologist. Professor Emeritus, University of Windsor, Canada. Interview by author. Skype, July 7, 2016.

${ }^{10}$ Nancy Knowlton, “Is There Room for Ocean Optimism on the Coral Reef Front?” May 7, 2016. https://imcc2016.wordpress.com/2016/07/05/is-there-room-for-ocean-optimism-on-thecoral-reef-front/

${ }^{11}$ Ben Halpern, Professor, Marine Ecology, University of California Santa Barbara. Interview by author. In-person, ICRS, Oahu. June 23, 2016.

${ }^{12}$ Irus Braverman, Wild Life: The Institution of Nature (Stanford: Stanford University Press, 2015).

${ }^{13}$ Nilda Jimenez Marrero, biologist, Puerto Rico Department of Natural Resources. Interview by author. In-person, Boqueron, PR, January 22, 2014.

14 https://twitter.com/SeaCitizens/status/745665511040552960

15 Ove Hoegh-Guldberg, "It's Not 'Doom and Gloom' to Point Out What's Really Happening to Coral Reefs." in The Conversation, March 3, 2016. https://theconversation.com/its-not-doomand-gloom-to-point-out-whats-really-happening-to-coral-reefs-55695

${ }^{16}$ Irus Braverman, Wild Life: The Institution of Nature (Stanford, Stanford University Press), pp. 45-48. 
${ }^{17}$ Sarah Frias-Torres. Marine ecologist. Interview by author. In-person, ICRS, Oahu. June 23, 2016. See also Nicole Helgason, "In The Seychelles, Scientists Are Getting Help From Nature's Cleanup Crew." in Reef Builders, November 9, 2015.

https://reefbuilders.com/2015/11/09/seychelles-scientists-natures-cleanup-crew/

18 Ibid.

${ }^{19}$ Dennis Normile, "Massive Bleaching Killed 35 Percent of the Coral on the Northern End of the Great Barrier Reef." in Science, May 30, 2016.

${ }^{20}$ Joanie Kleypas. Marine ecologist \& geologist. National Center for Atmospheric Research, Climate and Global Dynamics. Interview by author. In-person, ICRS, Oahu, June 23, 2016.

${ }^{21}$ NOAA. "US Coral Reefs Facing Warming Waters, Increased Bleaching.” June 20, 2016. http://www.noaa.gov/us-coral-reefs-facing-warming-waters-increased-bleaching

${ }^{22}$ Ibid. See also Ben Rosen, "Even As Bleaching Continues, Hope Remains For Coral Reefs." in The Christian Science Monitor, June 21, 2016.

http://www.csmonitor.com/Science/2016/0621/Even-as-bleaching-continues-hope-remains-forcoral-reefs

${ }^{23}$ NOAA. "Celebrating 200 Years.” http://celebrating200years.noaa.gov/magazine/coral_tech/

${ }^{24}$ Mark Eakin, Coordinator, NOAA Coral Reef Watch. Interview by author. Telephone, November 16, 2015. For a more detailed explanation of CRW's monitoring of bleaching see Irus Braverman, "Bleached! Governing Coral Catastrophe." in Futures (Forthcoming, 2016).

${ }^{25}$ Coral Reef Watch. (2015). Retrieved from http://coralreefwatchsatops. noaa.gov/VS/virtual_station_alerts.html

${ }^{26}$ Nancy Knowlton, Sant Chair in Marine Science, Smithsonian's National Museum of Natural History. Interview by author. Skype, July 11, 2016.

${ }^{27}$ William Skirving, NOAA Coral Reef Watch, Kirwan, Queensland, Australia. Interview by author. In-person, NOAA workshop, Hilo, HI. June 28, 2016.

${ }^{28}$ Daniel Cressey, "Coral Crisis: Great Barrier Reef bleaching is 'the worst we've ever seen."' in Nature, April 13, 2016. http://www.nature.com/news/coral-crisis-great-barrier-reef-bleachingisthe-worst-we-ve-ever-seen-1.19747

13. Retrieved from http://www.nature.com/news/coral-crisis-great-barrier-reef-bleaching-istheworst-we-ve-ever-seen-1.19747

29 "Australia's Censorship of Unesco Climate Report is Like a Shakespearean Tragedy." in The Guardian. May 30, 2016. http://www.theguardian.com/environment/planetoz/ 2016/may/30/australias-censorship-of-unesco-climate-report-is-like-a-shakespeareantragedy ${ }^{30}$ Ove Hoegh-Guldberg, n. 15.

${ }^{31}$ Ruth Gates, President, International Society for Reef Studies \& Professor, University of Hawai'i. Interview by author. Skype, January 25, 2016.

${ }^{32}$ See n. 6. See also Australian Institute of Marine Science, “'Assisted Evolution’ versus 'Genetic Modification.'” http://www.aims.gov.au/docs/media/featured-content.html//asset_publisher/Ydk18I5jDwF7/content/assisted-evolution-versus-genetic-modification

Irus Braverman is professor of law and adjunct professor of geography at University at Buffalo, the State University of New York (SUNY). She is author of Planted Flags: Trees, Land, and Law in Israel/Palestine (2009), Zooland: The Institution of Captivity (2012), and Wild Life: The Institution of Nature (2015). She is also co-editor of the collections The Expanding Spaces of Law: A Timely Legal Geography (with Nicholas Blomley, David Delaney and Alexandre Kedar; 
DRAFT. Anthropology Now. Volume 8 | Issue 2 | December 2016 (forthcoming)

2014) and Animals, Biopolitics, Law: Lively Legalities (2016). 